\title{
The Peer Counseling Model in Adolescents Reproductive Health for Senior High School Students
}

\author{
Indah Nurfazriah, ${ }^{1}$ Deni Kurniadi Sunjaya, ${ }^{2}$ Susi Susanah ${ }^{3}$ \\ ${ }^{1}$ STIKes Faletehan, Serang, Indonesia, ${ }^{2}$ Department of Public Health, Faculty of Medicine, \\ Universitas Padjadjaran, Bandung, Indonesia, ${ }^{3}$ Department of Child Health, Faculty of Medicine, \\ Universitas Padjadjaran/Dr. Hasan Sadikin General Hospital, Bandung, Indonesia
}

\begin{abstract}
Premarital sexual behavior in adolescents is at risk of sexual intercourse. One of the teenagers' factors in premarital sexual intercourse is a lack of knowledge about adolescent reproductive health. One method that can be given to increase knowledge about reproductive health is peer counseling. Peer counseling service improvement can be supported by the availability of modules or teaching materials to be used as a guide for peer counselors. The purpose of this study was to analyze the substance of the peer counseling module, analyze the perspective of the prospective module user on the development of peer counseling modules, and develop a model of the peer counseling module. The design of this study was the concurrent mixed method was divided into two stages, namely in-depth interviews with the experts and interviews and surveying with module users. The data was collected from the senior high school students in Cimahi and Bandung, West Java from March to July 2017. The result of this study showed that the substances developed in this module were the adolescents' reproductive health, adolescents' preparation in family planning, and adolescents' ethics. Based on results of the analysis using the Rasch model, in the module user's perspective, there is a need for the development of peer counseling modules. Evaluation of the module's model from participants showed that they mostly agreed with the module's model and the substances that were developed.
\end{abstract}

Key words: Adolescent, peer counseling, reproductive health

\section{Model Modul Konseling Sebaya dalam Kesehatan Reproduksi Remaja pada Siswa Sekolah Menengah Atas}

\begin{abstract}
Abstrak
Perilaku seksual pranikah pada remaja berisiko melakukan hubungan seksual. Salah satu faktor remaja melakukan hubungan seksual pranikah adalah pengetahuan tentang kesehatan reproduksi remaja yang kurang. Salah satu metode yang dapat diberikan untuk meningkatkan pengetahuan tentang kesehatan reproduksi adalah konseling sebaya. Peningkatan pelayanan konseling sebaya dapat ditunjang oleh ketersediaan modul atau bahan ajar sebagai panduan bagi konselor sebaya. Tujuan penelitian ini adalah menganalisis substansi modul konseling sebaya, menganalisis perspektif pengguna modul tentang pengembangan modul konseling sebaya, dan mengembangkan model modul konseling sebaya. Desain penelitian yang digunakan concurrent mixed methods yang dibagi menjadi dua tahap, yaitu wawancara mendalam dengan para pakar serta wawancara dan survei dengan pengguna modul. Data dikumpulkan dari siswa SMA di Cimahi dan Bandung, Jawa Barat mulai Maret hingga Juli 2017. Hasil penelitian menunjukkan bahwa substansi yang perlu dikembangkan dalam modul konseling sebaya adalah kesehatan reproduksi remaja, persiapan remaja dalam perencanaan keluarga, dan etika remaja. Berdasar atas hasil analisis menggunakan model Rasch, perspektif dari para pengguna modul adalah perlu pengembangan modul konseling sebaya. Evaluasi model modul dari partisipan menunjukkan bahwa kebanyakan mereka setuju dengan model modul dan substansi modul yang dikembangkan.
\end{abstract}

Kata kunci: Kesehatan reproduksi, konseling sebaya, remaja 


\section{Introduction}

The success of a nation's development can see from the quality of its human resources. Society is one of the essential components to realizing health development goals. ${ }^{1-4}$

Teenagers are a part of the community that has an essential role in constructing a nation. The young generation very needs information about reproductive health and family planning for a prosperous and quality life in the future. Lack of information about reproductive health in adolescents will trigger some problems such as premarital sex, HIV/AIDS and drug abuse, one of which will result in teenage pregnancy. ${ }^{5}$

Results of the Basic Health Research (Riset Kesehatan Dasar/Riskesdas) 2013 showed that there are still teenage pregnancies aged $<15$ years (0.02\%), especially in rural areas. The percentage of adolescents who have drunk alcoholic drinks is $40 \%$ done by young men and $5 \%$ by young women. The United Nations International Children's Emergency Fund (UNICEF) estimates that $18 \%$ of HIV/AIDS cases occur in the younger age group. ${ }^{6-8}$

To ensure maternal and child welfare more comprehensive efforts are needed to reduce the unwanted pregnancy rate of reproductive age couples, unfulfilled needs, teenage pregnancy (15-19years old), the unsustainable contraception (high discontinuation rates) and to increase participation in the use of contraception. ${ }^{9}$

The phenomenon of young marriage among teenagers is still a serious problem and requires special attention. Consequences of young marriage include lack of family harmony and lack of household sustainability so that it can lead to divorce. $^{10}$

The information about family planning should be socialized during adolescence. The National Population and Family Planning Board (Badan Kependudukan dan Keluarga Berencana Nasional/BKKBN) revived the Family Planning (Keluarga Berencana/KB) program in adolescents to prepare for married life and increase marriage age. Adolescents are a target of BKKBN programmed at socializing family planning because of the high rate of early marriage. One determining factor of early marriage is premarital sex. Many teenagers have sexual intercourse without knowledge about the unsafe impact of having sexual intercourse. ${ }^{11}$

West Java is the province with a high young population in Indonesia. According to BKKBN,
100 out of 1 ,000 young women aged $15^{-19}$ years in West Java were married (10\%), and 80 of them had unwed pregnancy. ${ }^{12}$

To respond to the complexity of adolescent problems, BKKBN created the Generation Planning (Generasi Berencana/GenRe) program to improve adolescent reproductive health, including family planning preparation. This program has existed for a long time, but it is reintroduced using a new term that is easier to memorize and suitable for teenagers. The GenRe program uses two approaches, both from the adolescents' view and the family's view. The approach to the view of the youth is carried out through the development of the Information and Counseling Center for Youth and College Students (Pusat Informasi dan Konseling Remaja/Mahasiswa [PIK R/M]). The approach from the family's or parent's view is carried out through the development of the Adolescents' Family Development (Bina Keluarga Remaja/ BKR) group. ${ }^{13,14}$

The PIK R/M program prepares and plans adolescents for family life, and this program is performed from, by, and for adolescents to provide information and counseling services about adolescent reproductive health. This program has been carried out and developed in all provinces in Indonesia with a total of 8,673 PIK R/M. ${ }^{15,16}$

Based on the results of a preliminary study conducted by Harini et al. ${ }^{16}$ about peer counselors are in the PIK R/M program, 50\% of adolescents admitted that they still lacked confidence when their friend (counselee) consulted about his/her problem and $30 \%$ of said they had not received information and knowledge about adolescent reproductive health. Furthermore, 20\% said that the media used in counseling such as leaflets, flipcharts, and modules are still limited.

Factors that can influence peer counselors in providing adolescent reproductive health (kesehatan reproduktifremaja/KRR) counseling based on results of Permatasari's ${ }^{17}$ study are sources of information such as television, mass media, schools and training, the counselor's knowledge of the counseling process and the motivation/support of BKKBN officers and coaches. The last two were the most dominant factors. ${ }^{18}$

The purpose of this study was to analyze the required substances of peer counseling modules in adolescent reproductive health based on indepth interview results with experts, investigating 
the user's perspective about the module, and develop a model of the peer counseling module.

\section{Methods}

This study uses mixed methods, which are the combination of two stages of qualitative and quantitative research. The design of this study was the concurrent mixed method by combining quantitative and qualitative data at one time using concurrent embedded strategies. ${ }^{19}$

There were two stages in this research, first is the collection of data with qualitative methods to analyze the required substance in peer counseling modules then we improve with research instruments by consulting with experts. Secondly, data is collected using qualitative and quantitative methods. The qualitative method at the second stage is to analyze the development needs and substance of peer counseling modules from module users. The quantitative method in this second stage was to conduct a survey to peer counselors for analyzing the extent and depth of development needs and the substance in the module.

The data was collected from the students of Public Senior High School (Sekolah Menengah Atas Negeri/SMA Negeri) 1 Cimahi, SMA Negeri 2 Cimahi, SMA Negeri 5 Cimahi, Public Vocational High School (Sekolah Menengah Kejuruan Negeri/SMK Negeri) 3 Cimahi, and SMK Negeri 6 Bandung, West Java province from March to July 2017.

The consideration of ethical issues of this research was approved by the Health Research Ethics Committee of Faculty of Medicine of Universitas Padjadjaran Bandung the letter of ethics approval number: 107/UN6.C1.3.2/KEPK/ $\mathrm{PN} / 2017$.

\section{Results}

The explanation of the qualitative substance of adolescent reproductive health in the peer counseling modules was adjusting to the characteristics of adolescent development. The material in the module must be attractive, challenging, and able to open up adolescents' insight, not informatively material.

The substance of this module includes several sub-modules, one of which is the adolescent reproductive health. Based on the transcript from informant 1 , the adolescent reproductive health of the youth counseling information center (pusat informasi dan konseling remaja/PIK R) curriculum was already complete, which includes three concepts of adolescent reproductive health (sexuality, HIV/AIDS, and drug abuse). The reproductive health material that necessary to be given to high school adolescents did not explain in detail. Not all schools are willing to accept the reproductive health curricula because it was already in biology subjects. Responding to this problem, stakeholders, especially the BKKBN of West Java was integrating reproductive health material into the subject of biology.

In line with the stages of adolescent development, the necessary reproductive health material provided was the process of menstruation, wet dream, sexual disorders, etc. That revealed by informant 2 :

"....menstruation process, wet dream, masturbation, that's all. It was not too detailed until the introduction of contraception." (T102R12)

The PIK R curriculum book has widely discussed adolescent reproductive health, but it did not include life skills. Life skills that were needed by high school students were revealed by informant 1:

"Actually in life skills, there is a discussion about how to knit. But it was more about mental endurance skills, ability to say no if, for example, her boyfriend asked her to have intercourse she must dare to say no." (T101R7)

The substance of reproductive health which necessary to be included in the peer counseling module was the reproductive period of adolescents; organs and reproductive functions; maintenance of reproductive organs; adolescent puberty and changes that occur; risks of sexual behavior; drugs abuse; and skills of adolescent life.

In the substance of adolescent preparation in family planning, information regarding the general description of marital life can providing to peer counselors, but it was must be provided when the teenager is about to get married because if it was provided too early by peer counselors, the information becomes not up to date.

The preparation of family planning is provided according to the needs of adolescents because not 
all adolescents will marry right after graduating from high school. Information about the process of menstruation, conception, pregnancy, and childbirth must be knowing by young women. Substances of adolescent preparation in family planning include ideal marriage age, marriage preparation, family planning, concepts, pregnancy and childbirth, and prevention of complications. It was according to the statement from informant 3:

"Yeah... it is necessary to provide all of that knowledge before they turn 17. It can be provided in stages 2...at the beginning of the 2nd grade." (TIo3R12)

The language used in the substance of family planning preparation should be adjusted to the characteristics of adolescents, as expressed by informant 9:

"....but the use of the language should be thought to make sure that they will not have misinterpretations about it." (T109R16)

Teenagers, in general, will set their mindset for the future after graduating from school, whether they will continue to college, work, or get married. The material about the ideal marriage age should be provided then adolescents can live in a healthy and prosperous household both physically and psychologically.

The substance of adolescent ethics must be able to teach ethical knowledge during their growth and development. It must be able to educate adolescents about healthy behavior. It can provide by parents at home and teachers at school.

Juvenile delinquency which occurs today is quite concerning. Teenagers are willing to experiment with new things that they have never done before. Once they try something new, it becomes a habit, and it will be difficult to remove. The development of science and technology and the influence of globalization will trigger various problems, especially among teenagers. These problems were the spread of moral issues such as narcotics and drug abuse, student brawls, pornography, rape, theft, abortion, fraud, persecution, gambling, prostitution, murder, etc. These problems have not been resolving thoroughly and fully.

The most common social problems in adolescents today are the low level of morals and ethics in their daily life, both at home, school and in the surrounding environment. Teaching ethics should begin when the child is familiar with the outside world. Good ethics will create good morals. Teenagers, in general, have been able to make decisions in determining their own lives, even though there are still contributions from parents.

The attention and support provided by the closest people to adolescents matter very much. Teenagers will have a determination to make decisions in their social life. Ethical teachings should include the basic concept of ethics, teenage ethics, and social manners.

During peer counseling, peer counselors must be able to provide information regarding reproductive health with real-life examples and adjusted to the characteristics of adolescent development. Language is constructed in a friendly way but must be inseparable from the norms, customs, and culture adopted by adolescents.

The peer counseling process divided into three phases. The first phase was building a relationship between peer counselors and adolescents. At this stage, the counselor must be able to understand the expressions of adolescents including their feelings and thoughts, explore adolescent problems, and encourage adolescents to make their own decisions. Counselors only explore the positive and negative side of each choice. Problem-solving was must base on the needs and characteristics of adolescents.

The counseling process can also be done based on the stages of greet, ask, tell, help, explain, return (GATHER). Dialogue is the most appropriate method during the peer counseling process because adolescents have creative and critical thinking potential. Characteristics of the adolescent that must be understood by peer counselors are the willingness to unite with their peers, and interest to the opposite sex.

Peer counselors have limited authority in providing counseling. Adolescent problems that are not resolved by peer counselors can be referred to a higher level, for example to the counseling teachers in school, psychologists, and health workers in public health services. The informant's expression in regarding the referral system in the peer counseling process was:

"Refer to the higher level...to the counseling 
teacher, not to a peer counselor. She/he can be referred to as the professional counselor." (T105R7)

The peer counselor's skills during the counseling process were able to make peer clients feel comfortable. The counselor must able to analyze the needs of their teenage clients. Organizations in the school environment were can used as a facility for peer counselors. Reference schemes for peer counselors must be provided in detail, to facilitate peer counselors if they face a situation that they cannot handle. Peer counselors must be able to know the limits of their abilities.

In the qualitative phase II based on module users, the counselors still had some difficulties, especially in providing information regarding problems that occur. Access to obtain information about the management of adolescent problems is still limited; this is according to what is revealed by an informant during in-depth interviews:

"Sometimes I search through Google, sometimes from a friend who has the same problems. Sharing between peer counselors before we share it with our counselee...."

The practice of counseling provided by peer counselors does not have to be formal, but it can be simple and in a relaxed situation known as curhat (vent). Counseling is provided to help adolescents to solve their problems as expressed by an informant:

"In my opinion, it should be better to talk about it. It's better to be open to each other." (T201R2)

Problems in adolescents are very complex, and sometimes peer counselors find it difficult to access information regarding problems that occur in adolescents. Some teenage problems that often occur were free sex, drug abuse, and HIV/AIDS. Some cases that occur in schools were different from the problems of adolescents in general, as revealed by informants:

"....it was about illness, painful menstruation, and also about love." (T2O1R5)

During counseling, peer counselors must be able to build good relationships and listening of clients actively so that clients can trust them as friends to share their feelings (curhat). An informant stated that:

"....counseling is like fostering good relations, we must trust each other so they will be open to us." (T201R8)

Counselors must build a sense of trust in their clients. In the counseling process, peer counselors must record in a log book the peer clients identity containing the initial names, addresses, classes, problems, problem-solving, and follow-up/referrals. The records will report to their counseling teacher or mentor. They will analyze the resolved and unresolved problems and follow up the problems solving they have been giving.

The reproductive health substance needs to be provided and known by high school teenagers. The material includes the adolescent preparation in family planning that explained in broadly speaking and not be too detailed. The purpose of this substance is to find the ideal age of marriage, management of independent life and responsibility as expressed by this informant:

"It is necessary, for information purposes only...." (T2O1R6)

Usually, reproductive health information was already to provide at the junior high school in the subject of biology, but gradual repetition is required to maintain reproductive health until they reach adulthood.

The media used in providing information for high school adolescents must be adjusting to norms or culture and religion. As revealed by this informant:

"According to my mother, the media is too exposing for high school students. There are matters that must not be known by adolescents." (T2O2R3)

The informant revealed that the media that was provided by the government was not suitable for adolescents, for example in the pamphlet about HIV/AIDS there are procedures for using condoms before sexual intercourse. According to the informant, this is not suitable for adolescents; therefore the development of peer counseling modules must be adjusted to the needs of the module users. 
Table 1 The Validity of the Instruments in Peer Counseling Modules about Adolescent Reproductive Health

\begin{tabular}{|c|c|c|c|c|c|c|c|c|c|c|c|c|c|}
\hline \multirow{2}{*}{$\begin{array}{c}\text { Entry } \\
\text { Number }\end{array}$} & \multirow{2}{*}{$\begin{array}{l}\text { Total } \\
\text { Score }\end{array}$} & \multirow{2}{*}{$\begin{array}{c}\text { Total } \\
\text { Count }\end{array}$} & \multirow{2}{*}{ Measure } & \multirow{2}{*}{$\begin{array}{l}\text { Model } \\
\text { SE }\end{array}$} & \multicolumn{2}{|c|}{ Infit } & \multicolumn{2}{|c|}{ Outfit } & \multicolumn{2}{|c|}{ PT-Measure } & \multicolumn{2}{|c|}{ Exact Match } & \multirow{2}{*}{ Item } \\
\hline & & & & & Mnsq & Zstd & Mnsq & Zstd & Corr. & Exp. & Obs\% & Exp\% & \\
\hline 2 & 74 & 30 & 1.63 & 0.35 & 0.87 & -0.5 & 0.90 & -0.4 & 0.79 & 0.35 & 80.0 & 62.2 & $\mathrm{~b}$ \\
\hline 4 & 74 & 30 & 1.63 & 0.35 & 1.28 & 1.3 & 1.23 & 1.1 & 0.33 & 0.35 & 56.7 & 62.2 & $\mathrm{~d}$ \\
\hline 3 & 75 & 30 & 1.50 & 0.35 & 0.74 & -1.2 & 0.73 & -1.3 & 0.46 & 0.35 & 70.0 & 62.0 & $\mathrm{c}$ \\
\hline 5 & 79 & 30 & 1.00 & 0.35 & 1.23 & 1.0 & 1.21 & 1.0 & 0.06 & 0.34 & 56.7 & 62.4 & $\mathrm{e}$ \\
\hline 8 & 79 & 30 & 1.00 & 0.35 & 0.75 & -1.1 & 0.74 & -1.2 & 0.37 & 0.34 & 66.7 & 62.4 & h \\
\hline 9 & 79 & 30 & 1.00 & 0.35 & 0.70 & -1.4 & 0.69 & -1.5 & 0.44 & 0.34 & $73 \cdot 3$ & 62.4 & $\mathrm{i}$ \\
\hline 13 & 83 & 30 & 0.49 & 0.36 & 1.18 & 0.8 & 1.22 & 0.9 & -0.14 & 0.33 & 70.0 & 67.0 & $\mathrm{~m}$ \\
\hline 16 & 84 & 30 & 0.36 & 0.37 & 0.58 & -1.8 & 0.56 & -1.9 & 0.33 & 0.33 & 80.0 & 68.7 & $\mathrm{p}$ \\
\hline 6 & 85 & 30 & 0.22 & 0.37 & 0.73 & -1.0 & 0.72 & -1.0 & 0.36 & 0.32 & 76.7 & 70.3 & f \\
\hline 7 & 87 & 30 & -0.05 & 0.37 & 0.97 & 0.0 & 0.97 & 0.0 & 0.48 & 0.32 & 70.0 & 72.7 & g \\
\hline 14 & 89 & 30 & -0.34 & 0.38 & 1.82 & 2.3 & 1.81 & 2.3 & 0.15 & 0.32 & 56.7 & 74.0 & $\mathrm{n}$ \\
\hline 15 & 91 & 30 & -0.62 & 0.38 & 0.61 & -1.4 & 0.61 & -1.4 & 0.37 & 0.32 & 83.3 & 74.2 & o \\
\hline 12 & 96 & 30 & -1.34 & 0.37 & 1.85 & 2.6 & 1.93 & 2.7 & 0.06 & 0.34 & 56.7 & 70.7 & 1 \\
\hline 10 & 98 & 30 & -1.61 & 0.37 & 0.78 & -0.9 & 0.78 & -0.8 & 0.57 & 0.34 & 73.3 & 68.5 & $\mathrm{j}$ \\
\hline 11 & 100 & 30 & -1.88 & 0.37 & 0.84 & -0.7 & 0.83 & -0.7 & 0.28 & 0.34 & 56.7 & $65 \cdot 9$ & $\mathrm{k}$ \\
\hline 1 & 108 & 30 & -2.98 & 0.38 & 0.99 & 0.0 & 0.99 & 0.0 & 0.55 & 0.31 & $83 \cdot 3$ & $64 \cdot 5$ & $\mathrm{a}$ \\
\hline Mean & 86.3 & 30.0 & 0.00 & 0.37 & 1.00 & -0.1 & 1.00 & -0.1 & & & 69.4 & 66.9 & \\
\hline $\mathrm{SD}$ & 9.8 & 0.0 & 1.33 & 0.01 & 0.38 & 1.3 & 0.39 & 1.3 & & & 9.7 & $4 \cdot 4$ & \\
\hline
\end{tabular}

SE: standard error; Infit: an information-weighted statistic; Outfit: an unweighted statistic; Mnsq: mean-square; Zstd: z-standardized; PT-Measure: an observed point-correlation; Exp.: expected value of the point-correlation; Obs\%: observed\%, the percent of data points; Exp\%: expected\%, the percent of data points

The adolescent was needed information about family planning. These based on this informant's expression:

"It is necessary; we must know that someday we will be married. From that information, we must know that we have to be more responsible with ourselves." (T203R7)

Teenagers will face diverse life challenges, and every teenager has a life plan. Harmonious and prosperous family life is a dream of every individual. The material about family planning preparation can provide an overview of the roles and responsibilities of a person in the family lived in the future.

A person's quality of life influenced by their principles of life. The development of life principles needs support from the closest persons such as family. The risks and threats in life can overcome with a positive attitude.

The assessment of peer counselor perspectives on the development needs and substance of peer counseling modules in adolescent reproductive

Table 2 Reliability of Instrument Used in This Study

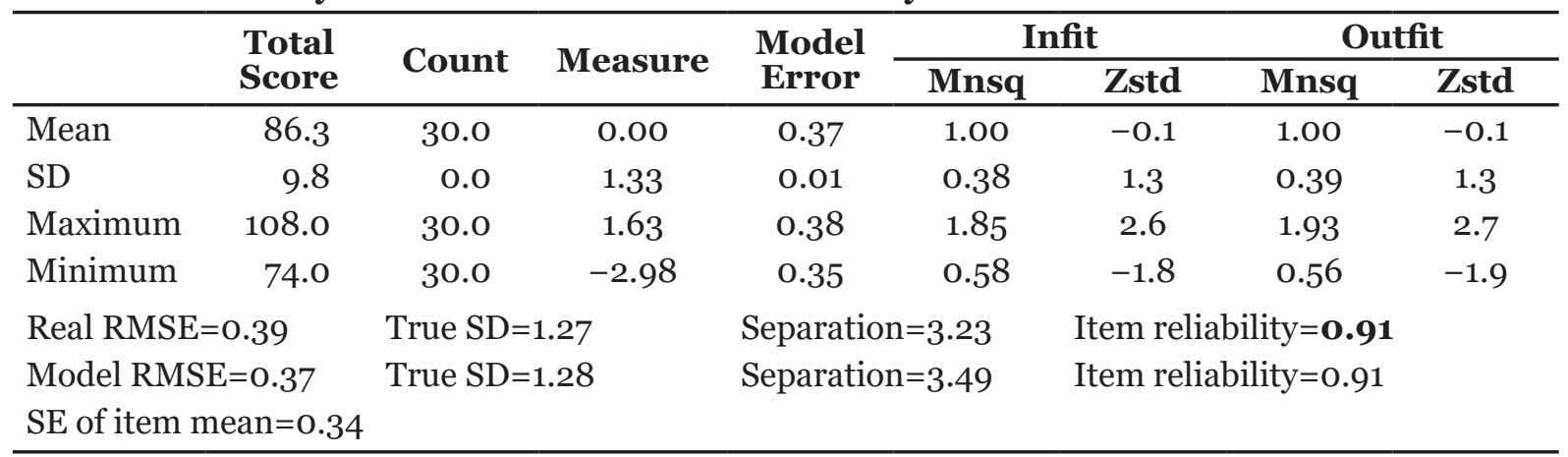

Infit: an information-weighted statistic, Outfit: an unweighted statistic, Mnsq: mean-square, Zstd: z-standardized; RMSE: root mean square errors, SE: standard error 
health from the survey results is strengthened by quantitative research methods, using instruments developed from the results of the stage I research (in-depth interview with the experts). Results of quantitative research obtain from providing questionnaires to 30 respondents (active peer counselors) in senior high schools in the Cimahi city and Bandung city.

Thirty respondents were included in this study, consisting of 7 male counselors and 23 female counselors. Active peer counselors were in the $11^{\text {th }}$-grade $\left(2^{\text {nd }}\right.$-grade in high school). We selected $11^{\text {th }}$-grade students because this class group already adapted to the school environment and peers and has not yet been scheduled to take the national examination.

Table 1 analyzes the level of reliability of the research instrument used by the researcher. The result the analysis showed that the instrument has a high level of reliability and can be accepted by respondents. Table 1 shows that all the items in the questionnaire meet the three Rasch modeling criteria so that all items in the peer counseling modules can be used in the study.

The instrument's reliability in this study was assessed based on the level of reliability. Reliable means can to be relied on and trustworthy. The reliability analysis in this study was conducted using the Rasch model by Winsteps software version 3.73. The criteria used to determine

Table 3 Person Measurement of Peer Counseling Modules about Adolescent Reproductive Health

\begin{tabular}{|c|c|c|c|c|c|c|c|c|c|c|c|c|c|}
\hline \multirow{2}{*}{$\begin{array}{c}\text { Entry } \\
\text { Number }\end{array}$} & \multirow{2}{*}{$\begin{array}{l}\text { Total } \\
\text { Score }\end{array}$} & \multirow{2}{*}{$\begin{array}{l}\text { Total } \\
\text { Count }\end{array}$} & \multirow{2}{*}{ Measure } & \multirow{2}{*}{$\begin{array}{c}\text { Model } \\
\text { SE }\end{array}$} & \multicolumn{2}{|c|}{ Infit } & \multicolumn{2}{|c|}{ Outfit } & \multicolumn{2}{|c|}{ PT-Measure } & \multicolumn{2}{|c|}{ Exact Match } & \multirow{2}{*}{ Person } \\
\hline & & & & & Mnsq & Zstd & Mnsq & Zstd & Corr. & Exp. & Obs\% & Exp\% & \\
\hline 3 & 52 & 16 & 3.08 & 0.53 & 1.33 & 0.9 & 1.28 & 0.8 & 0.32 & 0.55 & 62.5 & 72.5 & $\mathrm{CP}$ \\
\hline 5 & 52 & 16 & 3.08 & 0.53 & 0.85 & -0.3 & 0.82 & -0.4 & 0.62 & 0.55 & 75.0 & 72.5 & EP \\
\hline 10 & 51 & 16 & 2.81 & 0.52 & 0.43 & -1.8 & 0.58 & -1.2 & 0.58 & 0.55 & 93.8 & 72.0 & JP \\
\hline 4 & 50 & 16 & 2.54 & 0.52 & 0.96 & 0.0 & 0.97 & 0.1 & 0.37 & 0.55 & 68.8 & 70.9 & DP \\
\hline 2 & 49 & 16 & 2.28 & 0.51 & 1.36 & 1.0 & 1.33 & 0.9 & 0.72 & 0.54 & 43.8 & 69.7 & BP \\
\hline 1 & 48 & 16 & 2.02 & 0.50 & 1.22 & 0.7 & 1.22 & 0.7 & 0.45 & 0.54 & 68.8 & 68.5 & $\mathrm{AP}$ \\
\hline 22 & 48 & 16 & 2.02 & 0.50 & 0.67 & -1.0 & 0.67 & -0.9 & 0.58 & 0.54 & 81.3 & 68.5 & WP \\
\hline 23 & 48 & 16 & 2.02 & 0.50 & 0.67 & -1.0 & 0.67 & -0.9 & 0.58 & 0.54 & 81.3 & 68.5 & XP \\
\hline 8 & 47 & 16 & 1.77 & 0.50 & 1.51 & 1.4 & 1.45 & 1.3 & 0.77 & 0.54 & 56.3 & 67.0 & HP \\
\hline 9 & 47 & 16 & 1.77 & 0.50 & 0.84 & -0.4 & 0.84 & -0.4 & 0.76 & 0.54 & 62.5 & 67.0 & IP \\
\hline 14 & 47 & 16 & 1.77 & 0.50 & 1.62 & 1.7 & 1.61 & 1.6 & 0.32 & 0.54 & 62.5 & 67.0 & NP \\
\hline 18 & 47 & 16 & 1.77 & 0.50 & 1.17 & 0.6 & 1.18 & 0.6 & 0.34 & 0.54 & 62.5 & 67.0 & RL \\
\hline 20 & 47 & 16 & 1.77 & 0.50 & 0.62 & -1.2 & 0.63 & -1.1 & 0.47 & 0.54 & 87.5 & 67.0 & $\mathrm{TP}$ \\
\hline 21 & 47 & 16 & 1.77 & 0.50 & 0.62 & -1.2 & 0.63 & -1.1 & 0.47 & 0.54 & 87.5 & 67.0 & VP \\
\hline 16 & 46 & 16 & 1.52 & 0.50 & 0.62 & -1.2 & 0.58 & -1.3 & 0.78 & 0.54 & 75.0 & 65.7 & PL \\
\hline 24 & 46 & 16 & 1.52 & 0.50 & 0.92 & -0.1 & 0.93 & -0.1 & 0.60 & 0.54 & 62.5 & $65 \cdot 7$ & YP \\
\hline 17 & 45 & 16 & 1.28 & 0.49 & 0.79 & -0.6 & 0.78 & -0.6 & 0.75 & 0.54 & 68.8 & 65.2 & QL \\
\hline 26 & 45 & 16 & 1.28 & 0.49 & 0.72 & -0.9 & 0.71 & -0.8 & 0.77 & 0.54 & 68.8 & 65.2 & $\mathrm{AP}$ \\
\hline 27 & 45 & 16 & 1.28 & 0.49 & 0.91 & -0.2 & 0.92 & -0.1 & 0.67 & 0.54 & 68.8 & 65.2 & $\mathrm{BP}$ \\
\hline 7 & 44 & 16 & 1.03 & 0.49 & 0.50 & -1.9 & 0.47 & -1.9 & 0.57 & 0.55 & 87.5 & 64.1 & GP \\
\hline 12 & 44 & 16 & 1.03 & 0.49 & 1.21 & 0.7 & 1.26 & 0.8 & 0.73 & 0.55 & 62.5 & 64.1 & LP \\
\hline 15 & 44 & 16 & 1.03 & 0.49 & 0.79 & -0.6 & 0.81 & -0.5 & 0.30 & 0.55 & 75.0 & 64.1 & $\mathrm{OP}$ \\
\hline 29 & 44 & 16 & 1.03 & 0.49 & 0.97 & 0.0 & 0.98 & 0.1 & 0.68 & 0.55 & 62.5 & 64.1 & DP \\
\hline 11 & 43 & 16 & 0.79 & 0.49 & 0.55 & -1.6 & 0.53 & -1.6 & 0.58 & 0.55 & 81.3 & $65 \cdot 3$ & $\mathrm{KL}$ \\
\hline 25 & 43 & 16 & 0.79 & 0.49 & 1.17 & 0.6 & 1.20 & 0.7 & 0.59 & 0.55 & 68.8 & $65 \cdot 3$ & ZL \\
\hline 28 & 43 & 16 & 0.79 & 0.49 & 1.17 & 0.6 & 1.20 & 0.7 & 0.59 & 0.55 & 68.8 & 65.3 & $\mathrm{CP}$ \\
\hline 30 & 43 & 16 & 0.79 & 0.49 & 1.26 & 0.9 & 1.29 & 0.9 & 0.55 & 0.55 & 56.3 & 65.3 & EP \\
\hline 6 & 42 & 16 & 0.55 & 0.49 & 2.06 & 2.6 & 2.11 & 2.6 & 0.37 & 0.55 & 56.3 & 65.8 & FL \\
\hline 13 & 42 & 16 & 0.55 & 0.49 & 1.24 & 0.8 & 1.21 & 0.7 & 0.09 & 0.55 & 62.5 & 65.8 & MP \\
\hline 19 & 42 & 16 & 0.55 & 0.49 & 0.98 & 0.1 & 1.00 & 0.1 & 0.30 & 0.55 & 62.5 & 65.8 & SP \\
\hline Mean & 46.0 & 16.0 & 1.54 & 0.50 & 0.99 & 0.0 & 1.00 & 0.0 & & & 69.4 & 66.9 & \\
\hline $\mathrm{SD}$ & 2.8 & 0.0 & 0.71 & 0.01 & 0.36 & 1.1 & 0.36 & 1.0 & & & 11.1 & 2.4 & \\
\hline
\end{tabular}

SE: standard error; Infit: an information-weighted statistic; Outfit: an unweighted statistic; Mnsq: mean-square; Zstd: z-standardized; PT-Measure: an observed point-correlation; Exp.: expected value of the point-correlation; Obs\%: observed\%, the percent of data points; Exp\%: expected\%, the percent of data points 


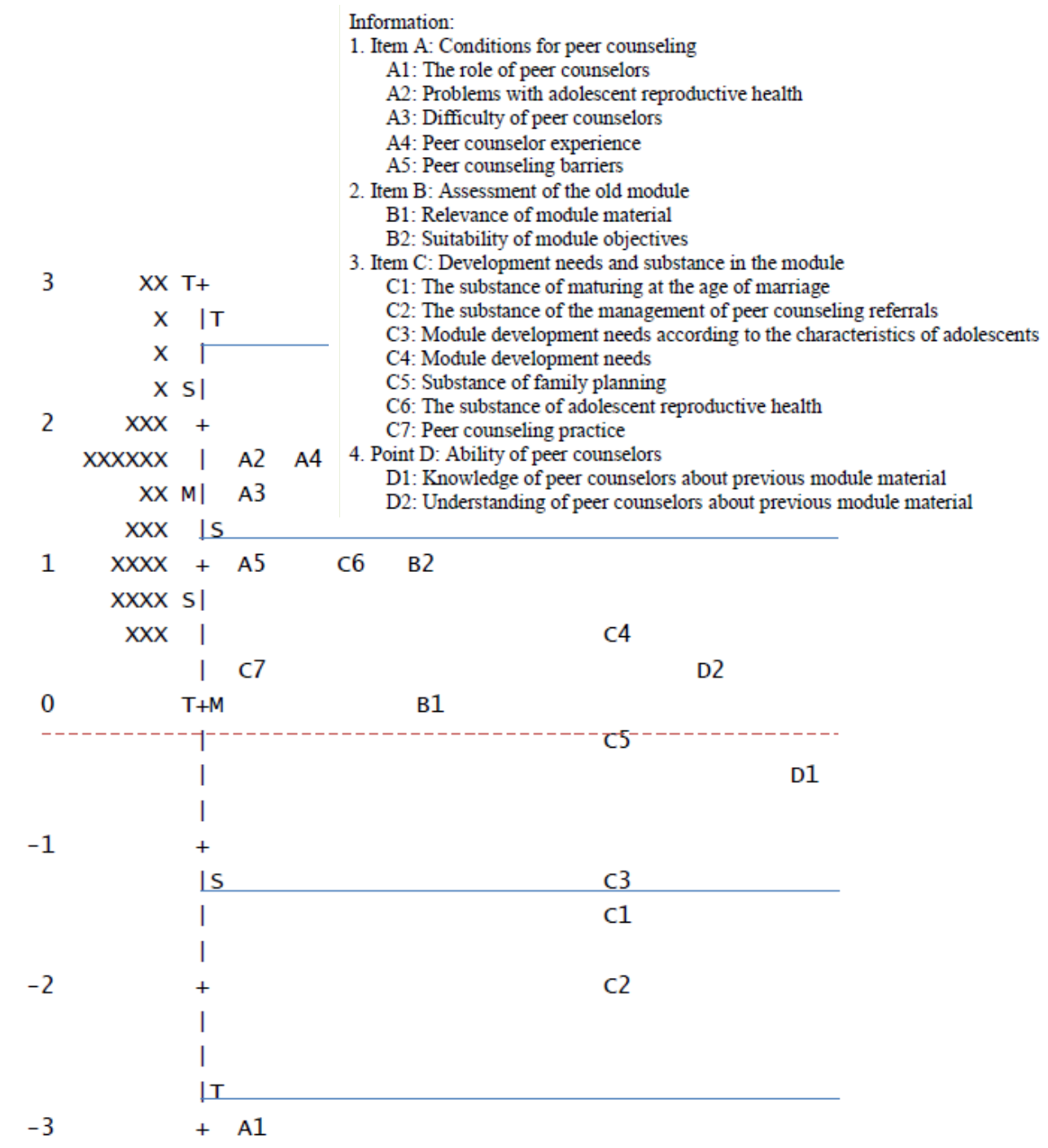

Figure Wright Map of the Needs and Substance of the Development of Peer Counseling Modules

the value of the person reliability and the item reliability are (a) weak: ${ }^{20}<0.67$, (b) adequate: o.67-0.80, (c) good: $0.81-0.90$, (d) very good: 0.91-0.94, and (e) special: >0.94.

Based on Table 2 it can be seen that the value of the reliability test was 0.91 . Referring to the reliability criteria that included in a very good category, the instrument of the peer counseling module was sufficient and can be used for research. The grouping of items can be known from the separation value, if the greater the separation value, the better the quality of the instrument.

Table 3 assesses the needs of peer counseling modules from the respondents' answers. It can be seen that when the logical value is more than 0.00 (1.54), the respondent agrees and surely needs the development of peer counseling modules.

On the wright map above there is an $\mathrm{X}$, which is the respondent who answers the research instrument, as a whole the respondents are above the o logical lines in the Rasch analysis model. All respondents agree and accept the statements contained in the instrument, meaning that the development needs of peer counseling modules are accepted. Points A, B, C, and D are items from the instrument, it can be seen in item $\mathrm{C}$ about the development needs and the substance 
of the peer counseling module spread in each column, meaning that item $\mathrm{C}$ is the best item among other items. There were 30 respondents (100\%) who agree to the items about substance in peer counseling modules consisting of the substance of adolescent reproductive health, the substance of maturing marital age, the substance of family planning, peer counseling practice, management of referrals in peer counseling, and module development needs according to the characteristics of adolescents.

The items about the previous module assessment seen in Figure are located above the o logical value marked letters B1 and B2. Based on the Rasch model, if there are items above the average value (o logical) means that the items are difficult for the respondents to approve. Item B1 is an assessment of the relevance of the contents of the previous module, and B2 is an assessment of the suitability of the objectives of the previous module with the expected user of the module.

\section{Discussion}

The results of the research in stage I show that experts agree with the development of modules on the substance of adolescent reproductive health. The material on adolescent reproductive health recommended by experts is still largely similar to the curriculum issued by the BKKBN for peer counselors.

The adolescent reproductive health material is the primary priority required by high schools students according to the characteristics of adolescents, while the substance included in the peer counseling module is as the following: adolescent reproductive organs and functions, maintenance of adolescent reproductive organs, puberty in adolescence, risky sexual behavior, drug and youth life skills.

Education/information about reproductive health needs to be invested as early as possible in adolescents, in this case, BKKBN is implementing a GenRe program that can help adolescents in obtaining accurate sources of information about reproductive health through peer counseling. One of the contents of reproductive health information in the KRR module includes the substance of three basic threats (tiga ancaman dasar/Triad) KRR, including sexuality, HIV/ AIDS, and drugs abuse. ${ }^{18}$

The user perspective of peer counseling modules on the need for module development in the substance of adolescent reproductive health organ can be seen from the results of the research which states that peer counselors agree with the development of modules on the substance of reproductive health. The results of the study using the Rasch modeling revealed a value of 0.54 logical in the personal measurement table. The need for the development of peer counseling modules is highly expected by module users, especially peer counselors.

The development of training and teaching material in the form of modules needs to be developed and updated according to the needs of the participants and stakeholders who provide training (trainer). The need for development is a must because it is adapted to the module users. ${ }^{21}$

Some experts agree with the substance of adolescent preparation of family planning in the counseling module. In adolescence (middle adolescent category), the possibility of life and the plan of life itself arises. After the graduation it varies, the general picture of family planning is provided when the teenager begins to show emotional development, one of the characteristics of emotional development is the attraction of the opposite sex that involves emotions (love, jealousy, and other emotions). ${ }^{22}$

Planning family life is based on an explanation of the ideal age of marriage (pendewasaan usia perkawinan/PUP). Teenagers are first provided information about the right age to get married. An explanation of the ideal age of marriage is listed in the curriculum prepared by the BKKBN. ${ }^{18}$

The development of other substances in this peer counseling module is related to adolescent ethics. Experts argue especially from the health department and obstetricians and gynecologists, that adolescents are faced with increasingly rapid technological developments. Adolescent behavior is much influenced by the environment and relationships both positive and negative. Improper use of technology will have an impact on adolescent behavior that is at risk. This risk behavior can be prevented by the existence of information about adolescent ethics in daily life at school and at home.

\section{Conclusions}

The substances developed in this module were the adolescents' reproductive health, adolescents' preparation in family planning, and adolescents' ethics. In the module user's perspective, there is 
a need for the development of peer counseling modules. Evaluation of the module's model from participants showed that they mostly agreed with the module's model and the substances that were developed.

\section{Conflict of Interest}

The author states that there is no conflict of interest.

\section{Acknowledgement}

The author would like to thank the families who have contributed to this article.

\section{References}

1. Helset S, Misvaer N. Adolescents' perceptions of quality of life: what it is and what matters. J Clin Nurs. 2010;19(9-10):1454-61.

2. Notoatmodjo S. Kesehatan dan pembangunan sumber daya manusia. KESMAS. 2008;2(2):195-9.

3. World Health Organization (WHO). Health for the world's adolescents: a second chance in the second decade. Geneva: WHO Press; 2014.

4. Hidayangsih SP. Perilaku berisiko dan permasalahan kesehatan reproduksi pada remaja. Kespro. 2014;5(2):89-101.

5. Pusat Data dan Informasi Kementerian Kesehatan Republik Indonesia. Situasi kesehatan reproduksi remaja. 29 Juni 2015 [cited 2017 July 30]. Available from: http://www.depkes.go.id/resources/ download/pusdatin/infodatin/infodatin\%20 reproduksi\%2oremaja-ed.pdf.

6. United Nations International Children's Emergency Fund (UNICEF) Indonesia. Ringkasan kajian: respon terhadap HIV \& AIDS. Oktober 2012 [cited 2017 July 30]. Available from: https://www.unicef.org/ indonesia/id/A4_-_B_Ringkasan_Kajian_ HIV.pdf.

7. Handayani S. Faktor-faktor yang mempengaruhi kejadian kehamilan tidak diinginkan pada remaja di Kelurahan Balecatur Ggamping Sleman Yogyakarta. JKSI. 2016;7(1):37-43.

8. Badan Kependudukan dan Keluarga Berencana Nasional. Laporan kinerja instansi pemerintah 2015: Badan Kependudukan dan
Keluarga Berencana Nasional. 2016 [cited 2017 August 1]. Available from: https://www. bkkbn.go.id/po-content/uploads/LAKIP_ BKKBN_2016.pdf.

9. Kementerian Kesehatan Republik Indonesia. Profil kesehatan indonesia 2014. Jakarta: Kementerian Kesehatan Republik Indonesia; 2015.

10. Susanti HA. Strategi komunikasi Badan Kependudukan dan Keluarga Berencana Nasional (BKKBN). J ASPIKOM. 2015;2(2): 243-54.

11. Dinas Kesehatan Kabupaten Bandung Barat. Artikel kesehatan reproduksi. Maret 27, 2015 [cited 2017 July 29]. Available from: http:// dinkes.bandungbaratkab.go.id/artikelkesehatan-reproduksi/.

12. Direktorat Bina Ketahanan Remaja Badan Kependudukan dan Keluarga Berencana Nasional.Pedoman pengelolaan binakeluarga remaja (BKR). Jakarta: Direktorat Bina Ketahanan Remaja Badan Kependudukan dan Keluarga Berencana Nasional; 2012.

13. Knowledge for Health (K4Health). Pusat informasi dan konseling kesehatan reproduksi remaja (PIK-KRR) [cited 2017 July 31]. Available from: https://www. k4health.org/sites/default/files/Bagian_II_ Program_Pemerintah_PIK-KRR.pdf.

14. Generasi Berencana (GenRe) Indonesia. BKR (bina keluarga remaja): latar belakang [cited 2017 July 31]. Available from: http://www. genreindonesia.com/bina-keluarga-remaja.

15. Rahmawati AH. Peningkatan keterampilan konseling konselor sebaya Pusat Informasi dan Konseling Remaja MAN Yogyakarta 1. JRMBK. 2016;5(4):1-12.

16. Harini R, Rahmat I, Nisman WA. Upaya peningkatan keterampilan konseling kesehatan reproduksi mahasiswa melalui pelatihan konselor sebaya. J Ners. 2014;9(2):173-82.

17. Permatasari D. Faktor-faktor yang mempengaruhi perilaku konselor sebaya dalam implementasi konseling kesehatan reproduksi remaja di Kabupaten Sumenep. Wiraraja Medika. 2013;3(2):82-7.

18. Direktorat Bina Ketahanan Remaja Badan Kependudukan dan Keluarga Berencana Nasional. Kurikulum diklat teknis pengelolaan PIK remaja/mahasiswa bagi pengelola, pendidik sebaya dan konselor sebaya PIK remaja/mahasiswa. $4^{\text {th }}$ Print. 
Jakarta: Direktorat Bina Ketahanan Remaja Badan Kependudukan dan Keluarga Berencana Nasional; 2013.

19. Satari MH, Wirakusumah FF. Konsistensi penelitian dalam bidang kesehatan. Bandung: Refika Aditama; 2011.

20. Sumintono B, Widhiarso W. Aplikasi model Rasch untuk penelitian ilmu-ilmu sosial. Revised Edition. Cimahi: Trim Komunikata Publishing House; 2014.
21. Peraturan Kepala Lembaga Administrasi Negara Nomor 5 Tahun 2009 tentang Pedoman Penulisan Modul Pendidikan dan Pelatihan.

22. Andriani P. Peran pusat informasi dan konseling (PIK-KRR) terhadap perilaku seksual berisiko pada SMPN terpilih di Jakarta Selatan tahun 2016. SEAJoM. 2016;2(1):13-23. 